Notes

\title{
THE PROBLEM OF USING HEARSAY IN DOMESTIC VIOLENCE CASES: IS A NEW EXCEPTION THE ANSWER?
}

\author{
NEAL A. HudDERS
}

\section{INTRODUCTION}

On the morning of September 6, 1993, the Honolulu Police Department received a report of a screaming female at a condominium complex. Upon his arrival at the scene, the responding officer observed a woman, Diana, bleeding from her chest. Diana told the responding officer, and then the emergency room physician, that her husband had stabbed her. Later that day, a police investigator conducted a tape-recorded interview with Diana at the hospital. Diana told the investigator that after a long argument her husband had jumped on her and, when she screamed, had put his hand on her throat. After punching her in the back, she said, he threw her in the closet and stabbed her with a kitchen knife. At her husband's trial for attempted second-degree murder, however, Diana's testimony was dramatically different-she claimed that the story she had given to the police was a lie and that she had grabbed the knife and stabbed herself. ${ }^{1}$

Diana's testimony presented the prosecutors with a serious problem. The only witness to the incident, Diana, was not willing to testify against her husband. The statements she had made to the police and medical personnel on the day of the incident were the prosecutor's only potential evidence, but they were classic hearsay. ${ }^{2}$ The

1. See State v. Clark, 926 P.2d 194, 196-98 (Haw. 1996).

2. "Hearsay," under Hawaiian law, is "a statement, other than one made by the declarant while testifying at the trial or hearing, offered in evidence to prove the truth of the matter asserted." HAW. R. EVID. 801(3). Hearsay is generally not admissible at trial except as otherwise provided. See id. 802. This definition of hearsay and the rule against hearsay in the Federal Rules are substantively identical. See FED. R. EvID. 801(c), 802; see also 2 MCCORMICK ON 
prosecutors were fortunate, however, because the court admitted the statements under several exceptions to the hearsay rule. The court determined that the statements to the responding officer and emergency room physician could be classified as excited utterances ${ }^{3}$ and thus excepted from the hearsay rule. ${ }^{4}$ Additionally, the court, applying Hawaii's prior inconsistent statement exception, ${ }^{5}$ held that the tape-recorded statement to the police investigator was admissible hearsay. ${ }^{6}$ On the strength of this evidence, Diana's husband was convicted of attempted second-degree murder, and the Hawaii Supreme Court affirmed the conviction.?

Not every domestic violence prosecutor is as fortunate as those in the case described above. A victim's hearsay statements may not fall easily into a hearsay exception or exclusion, ${ }^{8}$ and they may therefore not be available at trial. This Note examines the particular importance to prosecutors of a victim's hearsay statements in domestic violence cases, analyzes the methods by which these statements may be admitted into evidence, and argues that the adoption of a new hearsay exception for domestic violence is the most appropriate solution to the prosecutor's problem. Part I examines the situations in which prosecutors may need to use hearsay statements of the victim and the types of hearsay statements typically at issue. Part II focuses

EVIDENCE $§ 246$, at 96 (John W. Strong ed., 5th ed. 1999) (noting that the Federal Rules' definition of hearsay is followed by most states).

3. An "excited utterance," under Hawaiian law, is a "statement relating to a startling event or condition made while the declarant was under the stress of excitement caused by the event or condition." HAW. R. EvID. 803(b)(2). The Federal Rule is identical. See FED. R. EvID. 803(2); see also 2 MCCORMICK ON EVIDENCE, supra note 2, § 272, at 204-11 (discussing excited utterances generally).

4. See Clark, 926 P.2d at 202-03.

5. Under the Hawaii Rules of Evidence, a statement is not excluded by the hearsay rule if (1) the declarant is subject to cross-examination concerning the subject matter of the statement and the statement is inconsistent with the declarant's testimony, (2) the statement is offered in compliance with the rule governing the introduction of extrinsic evidence of prior statements, or (3) the statement was recorded in a substantially verbatim fashion by electrical means contemporaneously with the making of the statement. See HAW. R. EVID. 802.1(1). The Hawaii rule is broader than the Federal Rule, which allows prior inconsistent statements if the statement was "given under oath subject to the penalty of perjury at a trial, hearing, or other proceeding, or in a deposition." FED. R. EVID. 801(d)(1)(A). See infra Part II.A.2 for a discussion of the distinctions between Hawaii's rule and the Federal Rule.

6. See Clark, 926 P.2d at 199-200.

7. See id. at 196.

8. A statement falling under a hearsay exception is excepted from the hearsay rule and is admissible because it possesses otherwise sufficient guarantees of trustworthiness. See, e.g., FED. R. EVID. 803 advisory committee's note. A statement falling under a hearsay exclusion may literally fall within the definition of hearsay, but be explicitly excluded from the definition and therefore not considered hearsay. See, e.g., id. 801 advisory committee's note. 
specifically on how some jurisdictions are expanding existing hearsay exceptions in order to "solve" the problem, and it looks at decisions that appear to ignore the policy behind the hearsay rule. Part III addresses the possibility of a legislative solution through the creation of a statutory exception to the hearsay rule for domestic violence situations. It discusses the arguments for, and the barriers against, creating such an exception and critically examines a recently enacted hearsay exception for threats or infliction of injury. ${ }^{9}$ Finally, Part IV concludes that a new hearsay exception for domestic violence would be appropriate, and it discusses the elements such an exception would require.

\section{Domestic Violence And The HeARsay PRoblem}

Historically, the legal community, as well as society as a whole, has turned a blind eye to domestic violence, ${ }^{10}$ largely due to a reluctance to intrude into private matters such as family relations. ${ }^{11} \mathrm{Al}-$ though both the legal community and society generally have come a long way in recognizing the problem of domestic violence, ${ }^{12}$ the scope of the continuing problem is daunting. In the United States from $1987-1991$, there were on average more than 600,000 victims of domestic violence each year; females constituted more than $90 \%$ of the victims. ${ }^{13}$ During this four-year span, women who were the victims of

\footnotetext{
9. See CAL. Evid. CodE $§ 1370$ (West Supp. 1999).

10. See Myrna S. Raeder, The Admissibility of Prior Acts of Domestic Violence: Simpson and Beyond, 69 S. CAL. L. REV. 1463, 1466, 1516-17 (1996) (discussing how and why abuse of women has been ignored and proposing a domestic homicide exception to the evidentiary rule excluding hearsay "to correct gender biases that have blinded us for too long"); Melanie Frager Griffith, Note, Battered Woman Syndrome: A Tool for Batterers?, 64 FORDHAM L. REV. 141, 150 (1995) ("Throughout history, society has tolerated - even legally sanctioned - abuse against women."). For the purposes of this Note, domestic violence can be defined as "the use of physical or psychological force by one adult against another adult with whom there currently exists, or has existed, an intimate relationship." Naomi R. Cahn, Civil Images of Battered Women: The Impact of Domestic Violence on Child Custody Decisions, 44 VAND. L. REV. 1041, 1042 n.5 (1991).

11. See State v. Rhodes, 61 N.C. 453, 459 (1868) ("We will not inflict upon society the greater evil of raising the curtain upon domestic privacy, to punish the lesser evil of trifling violence."); Raeder, supra note 10, at 1466 (arguing that the societal desire to keep domestic violence "hidden from public view" stems from the pervasive problem of gender bias); James Martin Truss, Comment, The Subjection of Women ... Still: Unfulfilled Promises of Protection for Women Victims of Domestic Violence, 26 ST. MARY's L.J. 1149, 1150 (1995) (recognizing judges' reluctance to intrude into these "family matters").

12. See Raeder, supra note 10, at 1466 (noting some progress in addressing this serious problem); Griffith, supra note 10, at 156-60 (recognizing the increased awareness and concern
} about domestic violence as a problem, but noting the continuing existence of a problem).

13. See Ronet Bachman, U.S. Dep'T of Justice, Violence Against Women: A National CRime Victimization SurVey Report 6 (1994). 
domestic violence were also twice as likely to receive an injury and to require medical care than women who were victimized by strangers. ${ }^{14}$ Additionally, $20 \%$ of women victimized by their current or former spouses reported that they had been victims of a series of three or more similar assaults within the previous six months. ${ }^{15}$ Approximately two thousand women are killed by their batterers each year. ${ }^{16}$

Domestic violence is no longer perceived to be solely a private matter; it is also a societal problem. ${ }^{17}$ Domestic violence impacts not only the abuser and the abused, but children, the extended family, coworkers, and others. ${ }^{18}$ Yet, despite the social impact of domestic violence, the violence usually takes place in private, where only the abuser and the abused are present. ${ }^{19}$ This presents a significant problem for prosecutors. Constitutional prohibitions preclude the prosecutor from compelling the accused to testify against himself. ${ }^{20}$ Thus, the testimony of the victim becomes an essential element of the prosecution's case. The victim, however, is often unavailable because she has been killed, ${ }^{21}$ is unwilling to testify, ${ }^{22}$ or is otherwise unavailable. ${ }^{23}$ In these situations, a victim's hearsay statements can become the only opportunity for the prosecutor to bring in the victim's "voice" at trial. $^{24}$

\footnotetext{
14. See id. at 8 .

15. See Bureau of Justice Statistics, U.S. Dep'T of Justice, Violence Between INTIMATES 2 (1994).

16. See Raeder, supra note 10, at 1469 (citing various statistics of deaths from domestic violence).

17. See Donna Wills, Domestic Violence: The Case for Aggressiveness for Prosecution, 7 UCLA WOMEN's L.J. 173, 174 (1997) (emphasizing the broad societal, not just individual, impact of domestic violence).

18. See id.

19. Assaults may frequently be witnessed by children, see id. at 175 , but children may often be incapable of serving as testifying witnesses at a trial, for a variety of reasons. See, e.g., IND. CODE. ANN. § 35-37-4-6(d)(2)(B) (Michie 1998) (defining categories in which a child may be found to be unavailable as a witness).

20. See U.S. CONST. amend. V.

21. See, e.g., State v. Bell, 950 S.W.2d 482 (Mo. 1997); Browne v. State, 933 P.2d 187 (Nev. 1997).

22. See, e.g., State v. MacArthur, 644 A.2d 68 (N.H. 1994) (involving a victim who recanted prior statements implicating the defendant); State v. Marcy, 680 A.2d 76 (Vt. 1996) (featuring a victim who testified at trial that she could not remember what happened).

23. See, e.g., Jay v. State, 503 S.E.2d 563 (Ga. Ct. App. 1998) (illustrating the difficulties presented by a victim's disappearing three weeks before the trial).

24. If the victim chooses to recant an earlier story, her voice is obviously heard at the trial. In these situations, it is the earlier statements of the victim, contradicting her testimony, which the prosecutor seeks to introduce.
} 


\section{A. Situations in Which the Domestic Violence Victim Has Died}

When a victim of domestic violence has died, the need to use her hearsay statements is clearest. Any relevant statements made by the victim and introduced to prove the truth of the matter asserted are hearsay. ${ }^{25}$ A prosecutor, however, may still use the statements if they fall within an established exception to the hearsay rule. Such exceptions to the rule are considered to possess sufficient guarantees of trustworthiness other than those provided by direct testimony. ${ }^{26}$ For example, a statement made by a victim and heard by a third party, while still under the stress resulting from an assault, may be admissible under the excited utterance exception to the hearsay rule. ${ }^{27}$ This exception has been used to introduce a victim's statements regarding past abuse, ${ }^{28}$ as well as responses made by the victim prior to death. ${ }^{29}$ Similarly, the present sense impression exception, which excepts from the hearsay rule statements describing or explaining an event or condition made while the victim was perceiving the event or condition, ${ }^{30}$

25. See, e.g., FED. R. EVID. 801(c). The prosecutor will also be faced with a Confrontation Clause problem. The Constitution requires that "[i]n all criminal prosecutions, the accused shall enjoy the right ... to be confronted with the witnesses against him." U.S. CONST. amend. VI; see also 2 MCCORMICK ON EVIDENCE, supra note 2, § 252, at 121-26 (discussing the problems of confrontation and due process). Under current Supreme Court jurisprudence, however, the right to confrontation is nearly indistinguishable from the hearsay rule. See Patricia W. Bennett, After White v. Illinois: Fundamental Guarantees to a Hollow Right to Confront Witnesses, 40 WAYNE L. REV. 159, 188-89 (1993) (arguing that the Court "eviscerate[d]" the Confrontation Clause in its decision in White v. Illinois by allowing the state to secure a conviction with evidence from an available declarant who never appeared at the trial and was never crossexamined).

26. See FED. R. EVID. 803 advisory committee's note; 2 MCCORMICK ON EVIDENCE, supra note $2, \S 253$, at $126-27$.

27. See FED. R. Evid. 803(2); 2 MCCORMICK ON EVIDENCE, supra note 2, § 272, at 204-11.

28. See, e.g., Commonwealth v. Snell, 705 N.E.2d 236, 244 (Mass. 1999) (allowing the neighbor of the deceased victim to testify as to the victim's plea for help and her expressed fear that her husband was trying to "choke her and smother her with a pillow"); State v. Murillo, 509 S.E.2d 752, 759-62 (N.C. 1998) (ruling that conversations about past abuse held between the deceased victim and various family members and friends were admissible as excited utterances because the victim had described the beatings immediately after they had occurred).

29. See, e.g., State v. Simko, 644 N.E.2d 345, 352 (Ohio 1994) (admitting (as an excited utterance) a nod by an intubated victim responding to a police question). In Simko, the prosecution also attempted to introduce the victim's statement as a dying declaration. See id. at 351-52. A dying declaration is an exception to the hearsay rule when the declarant is (obviously) unavailable. The Ohio rules define a dying declaration as "a statement made by a declarant, while believing that his or her death was imminent, concerning the cause or circumstances of what the declarant believed to be his or her impending death.” OHIO R. EvID. 804(b)(2) (West 1994). Because the Simko court determined that the victim did not believe that death was imminent, the statement was not admissible as a dying declaration. See Simko, 644 N.E.2d at 351-52.

30. See, e.g., FED. R. EvID. 803(1); 2 MCCORMICK ON EVIDENCE, supra note 2, § 271, at 200-04 (discussing present sense impressions generally). 
has also been applied. ${ }^{31}$ This exception, however, is used less frequently than the excited utterance exception because it requires more precise contemporaneity. ${ }^{32}$ Other exceptions that have been used, often to show instances of prior abuse, include the state of mind exception, ${ }^{33}$ the business records exception, ${ }^{34}$ and the residual exception. ${ }^{35}$

31. See, e.g., Thomas v. State, 973 S.W.2d 1, 4 (Ark. Ct. App. 1998) (ruling admissible (as a present sense impression) statements made by the victim in a telephone conversation describing being held at gunpoint by the defendant).

32. The present sense impression exception allows a slight lapse, recognizing that precise contemporaneity is not possible. With respect to the excited utterance, there is no set time, merely the duration of the state of excitement, which will vary depending on the character of the transaction or event. See FeD. R. EvID. 803(1) \& 803(2) advisory committee's note; 2 MCCORMICK ON EVIDENCE, supra note 2, § 271, at 202-03; see also Browne v. State, 933 P.2d 187, 191 (Nev. 1997) (holding that the trial court, in disregard of the contemporaneity requirement, erroneously admitted the victim's description of abuse as a present sense impression, but holding further that, since the description was not offered to prove the truth of the matter but to provide a foundation for the witness's opinion that the marriage was bad, the statement was not hearsay).

33. See, e.g., FED. R. EvID. 803(3) (excepting from the hearsay rule statements of the declarant's "then existing state of mind, emotion, sensation, or physical condition (such as intent, plan, motive, design, mental feeling, pain, and bodily health), but not including a statement of memory or belief to prove the fact remembered or believed," unless the terms of a will are in dispute); State v. Wood, 881 P.2d 1158, 1167-68 (Ariz. 1994) (en banc) (holding that the victim's statements, indicating fear and a desire to end a relationship, helped to explain the defendant's motive, a disputed issue at trial, and that they were therefore admissible); State v. Alston, 298 S.E.2d 631, 637 (N.C. 1983) (holding that, although a victim's statements demonstrating ill will between the victim and the defendant must be carefully scrutinized, they are admissible to show premeditation, deliberation, motive, and intent); 2 MCCORMICK ON EVIDENCE, supra note 2, $\S \S$ 273-76, at 214-32 (discussing the state of mind exception to the hearsay rule).

34. See, e.g., FED. R. EVID. 803(6) (excepting from the hearsay rule any form of record of "acts, events, conditions, opinion, or diagnoses" made by a person with knowledge, provided that the record was kept "in the course of a regularly conducted business activity" and that "it was the regular practice" of the business to create the type of record); State v. Scott, 471 S.E.2d $605,617-18$ (N.C. 1996) (determining that a form completed by the victim upon entrance to an abused women's shelter was admissible as a business record); 2 MCCORMICK ON EVIDENCE, supra note $2, \S \S 284-94$, at 248-70 (discussing the hearsay exception for regularly kept records generally). This exception is used with less frequency because the exception is generally not applicable to police reports. See, e.g., State v. Spinks, 607 N.E.2d 1130, 1136 (Ohio Ct. App. 1992) (holding that the business records exception does not permit the state to prove its case through police records or reports); 2 MCCORMICK ON EvIDENCE, supra note 2, § 296, at 275-78 (discussing the debate over the restrictions on police reports).

35. See, e.g., FED. R. EVID. 807 (excepting from the hearsay rule statements not specifically covered under another exception but having "equivalent guarantees of trustworthiness," provided that the statement is offered as evidence of a material fact, that it is more probative on the point than other evidence that can be procured through reasonable efforts, and that the interests of justice are best served by inclusion); State v. Grube, 531 N.W.2d 484, 489-90 (finding reasons to admit certain statements into the record even though they did not fall "within a firmlyrooted exception to the hearsay rule") (Minn. 1995); 2 MCCORMICK ON EVIDENCE, supra note 2 , § 324, at 343-51 (discussing residual hearsay exceptions generally); see also infra notes 62-63 and accompanying text. 


\section{B. Situations in Which the Domestic Violence Victim Is Alive}

Where the victim of domestic violence is still alive, the prosecution problem is more complex. Many domestic violence victims are unwilling to testify against their abusers. ${ }^{36}$ This unwillingness may result in the victim's either dropping the charges or refusing to appear as a witness, both of which often lead to a dismissal of the case. ${ }^{37} \mathrm{~A}$ number of jurisdictions, however, have adopted "no-drop" policies, under which a victim cannot freely withdraw a complaint once formal charges have been filed. In these jurisdictions, the prosecutor's discretion to drop a case because the victim is unwilling to cooperate is limited. ${ }^{38}$ Even in these jurisdictions, however, the prosecutor faces an uphill battle if a victim is unwilling to testify because the prosecutor must provide evidence of domestic violence without the direct testimony of the victim. ${ }^{39}$

36. For example, according to the experience of the city attorney's office in Duluth, Minnesota, only $4 \%$ of domestic violence victims were actively willing to testify against their abusers. See Mary Asmus et al., Prosecuting Domestic Abuse Cases in Duluth: Developing Effective Prosecution Strategies from Understanding the Dynamics of Abusive Relationships, 15 HAMLINE L. REV. 115, 139 \& n.108 (1991). For a discussion of some of the reasons why victims are unwilling to testify, see infra notes 40-49 and accompanying text.

37. See Eve S. Buzawa \& Carl G. Buzawa, Domestic Violence: The Criminal JUSTICE RESPONSE 87 (2d ed. 1996) (estimating that attrition rates for victim-initiated cases range between $60-80 \%$ ).

38. See Angela Corsilles, Note, No-Drop Policies in the Prosecution of Domestic Violence Cases: Guarantee to Action or Dangerous Solution?, 63 FORDHAM L. REV. 853, 856 (1994). Nodrop policies are controversial because of the potential conflict between the victim's concern for her future safety and the goal of bringing domestic violence perpetrators to justice. For a discussion of the merits of such policies, compare Linda G. Mills, Intuition and Insight: A New Job Description for the Battered Woman's Prosecutor and Other More Modest Proposals, 7 UCLA WOMEN's L.J. 183, 190-91 (1997) ("Perversely, in all too many cases, the effect of mandatory policies is to align the battered woman with her batterer, to protect him, and to further entrench her in the abusive relationship."), with Wills, supra note 17, at 180 ("A 'no drop' policy means prosecutors will not allow batterers to control the system of justice through their victims."); see also BUZAWA \& BUZAWA, supra note 37, at 177-81 (advancing six justifications for "no-drop" policies); Kalyani Robbins, No-Drop Prosecutions of Domestic Violence: Just Good Policy or Equal Protection Mandate?, 52 STAN. L. REV. 205, 216 (1999) ("With a no-drop policy, either the victim must testify or the prosecutor must use other evidence . . . but either way the case must proceed to trial.").

39. See Asmus et al., supra note 36, at 139. This problem would also be evident in a jurisdiction that does not have a "no-drop" policy, but decides to continue prosecution despite a victim's unwillingness to testify. Such a situation would be rare, however, because of a general reluctance on the part of prosecutors to prosecute domestic violence cases. Cf. Corsilles, supra note 38, at 867 ("Because the victim is often the only witness to the violence, such cases can be extremely difficult to prove without the victim's testimony."). This reluctance stems from a combination of factors ranging from a failure to understand the dynamics of domestic violence to a desire to achieve higher conviction rates while conserving limited prosecutorial resources. See id. at 866-70. 
A victim's decision not to testify may be motivated by several factors. First, a victim may be dissatisfied with the criminal justice system once she enters it. ${ }^{40}$ This dissatisfaction may arise because the victim is simply unprepared for the realities of the criminal justice process, ${ }^{41}$ or because court personnel make the victim feel personally responsible for her abuse..$^{42}$ Second, the victim may be subject to physical retaliation or intimidation by the offender. ${ }^{43}$ The offender may also provoke the victim's fears of economic harm by threatening loss of financial support. ${ }^{44}$ Third, the cyclical nature of domestic abuse can result in a lull in abuse, during which a reconciliation may occur between the victim and the abuser. ${ }^{45}$ The continuing criminal case may be the only reminder of the incident, and, given the positive current state of the relationship, the victim may become unwilling to testify. ${ }^{46}$ Fourth, many victims may partially or entirely attribute the cause of the abuse to their own conduct. ${ }^{47}$ This self-accusation, com-

40. See Corsilles, supra note 38 , at 870 (cataloguing the ways in which battered women can be disappointed with the modern criminal justice process).

41. See id. ("Like other victims, battered women are unprepared for the number of court appearances, the lack of input they have about plea negotiations and sentencing, and the amount of protection the defendant receives for his constitutional rights.").

42. See BUZAWA \& BUZAWA, supra note 37, at 87 (arguing that prosecutorial staff are not aware of the violation to the public order engendered by such abuses and are thus ambivalent about intervening in private disputes).

43. See id. at 88 (noting that nearly half of the victims in one study reported that their assailants had threatened them and that $25 \%$ of those victims' assailants had threatened to kidnap the victims' children if they continued court procedures) (citing A. KLEIN, SPOUSAL/PARTNER Assault: A Protocol fOr the Sentencing AND SUPERVISION OF OfFenders (1994)); Corsilles, supra note 38 , at $870 \&$ n. 126 ("A domestic abuse victim is more than twice as likely as other victims of violent crimes to be revictimized within six months after the assault that gave rise to the legal intervention." (referencing Barbara Hart, Battered Women and the Criminal Justice System, 36 AM. BEHAV. SCI. 624, 625 (1993))).

44. See BUZAWA \& BUZAWA, supra note 37 , at $88-89$. In addition to threats, victims also encounter real possibilities of indirect economic harm by continuing prosecution, including the offender's possible loss of job, loss of alimony or child support, and actual out-of-pocket expenses in the event of a conviction or extensive court time. Direct economic harm may also result if the victim is required to take time from her own job and to arrange for child care to make court appearances. See id.; see also Corsilles, supra note 38, at 871 ("[W]here the woman has no income independent of the batterer, the decision to continue prosecution may result in destitution for the entire family.").

45. See BuZAWA \& BUZAWA, supra note 37, at 89 (noting that the "cyclic nature" of battering may result in "honeymoons" without abuse); see also LENORE WALKER, THE BATTERED WOMAN 55-70 (1979) (delineating the three phases in the cycle theory of violence); Joan M. Schroeder, Note, Using Battered Woman Syndrome Evidence in the Prosecution of a Batterer, 76 IOWA L. REV. 553, 557-59 (1991) (discussing generally the cycle theory of violence).

46. See BUZAWA \& BUZAWA, supra note 37, at 89 (noting that continuing the prosecution can end a "harmonious" period between the couple).

47. See id. ("Feminists would, of course, observe that such a result is predictable given the socialization process reinforced by constant societal pressure."); Schroeder, supra note 45 , at 
bined with the cyclical nature of an abusive relationship, may be symptomatic of battered woman syndrome, one explanation of why some women remain in abusive relationships. ${ }^{48}$ Finally, the victim may use the threat of prosecution to gain control in an abusive relationship. The actual prosecution may be of secondary importance to the victim, as long as she gains a measure of control. ${ }^{49}$

If the victim decides not to cooperate in a domestic violence prosecution, her decision can manifest itself in several ways. First, the victim may recant prior statements. For example, the victim may give a statement to law enforcement authorities immediately following a domestic violence incident, then disavow her statement at trial, as in the situation described in the Introduction..$^{50}$ In that example, because of these inconsistencies, the prosecutor was able to apply Hawaii's prior inconsistent statement exception to the hearsay rule, ${ }^{51}$ as well as the exception for excited utterances. ${ }^{52}$

Second, a victim may not remember, or may claim not to remember, the abusive incident when testifying at trial. ${ }^{53}$ For example,

558 ("Battered women ... place blame for the battering on their own failures or external situations.").

48. See Schroeder, supra note 45, at 557-61 (considering various explanations of why women remain with their batterers). The theory of battered woman syndrome was first introduced by Lenore Walker and has two general components: the cycle of violence and learned helplessness. The cycle of violence involves three phases: a tension-building phase, an acute battering phase, and a calming phase. See WALKER, supra note 45, at 55-70. Learned helplessness is a belief, acquired by an abused woman, that she cannot control what happens to her. See id. at $42-54$.

49. See BUZAWA \& BUZAWA, supra note 37, at 90 ("[T] he criminal justice system is used as a strategic tool of the victim ...."); Corsilles, supra note 38, at 872 ("Some victims withdraw from prosecution because they have effectively wielded the threat of prosecution as a "power resource' in bargaining for their own safety.").

50. See supra notes 1-7 and accompanying text.

51. See State v. Clark, 926 P.2d 194, 199-200 (Haw. 1996). The prior inconsistent statement exception is often used in situations in which the victim recants her prior statements. See, e.g., State v. Borelli, 629 A.2d 1105, 1109-10 (Conn. 1993); State v. Tomas, 933 P.2d 90, 95 (Haw. Ct. App. 1997); State v. MacArthur, 644 A.2d 68, 70 (N.H. 1994). The application of this exception can vary depending on how broadly or narrowly a particular jurisdiction writes or interprets its statute. See infra Part II.A.2 for a more detailed discussion of these variations.

52. See Clark, 926 P.2d at 202-03 (finding that the victim's statements to the responding officer and the emergency room physician could be classified as excited utterances).

53. A domestic violence victim could be suffering from post-traumatic stress disorder ("PTSD"), of which memory loss is one symptom. See Linda Kelly, Stories from the Front: Seeking Refuge for Battered Immigrants in the Violence Against Women Act, 92 Nw. U. L. ReV. 665, 702 (1998) (noting the similarities between PTSD and "rape trauma syndrome"); Joan S. Meier, Notes from the Underground: Integrating Psychological and Legal Perspectives on Domestic Violence in Theory and Practice, 21 HoFsTRA L. REV. 1295, 1312-14 (1993) (identifying in battered women the three symptoms associated with PTSD). 
in State v. Todd, ${ }^{54}$ a victim who had been recently battered recounted to several individuals the events that led to her injuries, and her statements implicated the defendant. ${ }^{55}$ At trial, however, the victim claimed that she could not remember how she had received her injuries. As a result, much of the prosecution's case relied on the hearsay statements of the people to whom the victim had spoken regarding the source of her injuries. ${ }^{56}$ The trial court admitted these statements under the excited utterance, present sense impression, and state of mind exceptions to the hearsay rule. ${ }^{57}$

The third situation occurs when the victim simply does not appear. For example, in Jay v. State, ${ }^{58}$ the victim disappeared three weeks prior to trial..$^{59}$ Despite a good-faith effort to locate the victim, the state could not find her, and the trial was held, with the trial court admitting victim's statements under the res gestae exception to the hearsay rule. ${ }^{60}$

54. 954 P.2d 1 (Kan. Ct. App. 1998).

55. See id. at 2-3.

56. See id. at 3. Affirming the trial court, the appellate court noted that the victim had initially indicated that she did not want to press charges, and it held that, for the purposes of hearsay exceptions, the victim was not "unavailable" simply because she claimed that she could not remember the incident, implying that a sincere loss of memory would render the victim unavailable for the purposes of hearsay exceptions. See id. at 3, 5 ("'This is not a case where a witness, acting in good faith, was unable to testify as to the subject matter of her prior statement because, through no fault of her own, she had lost her memory in regard to such events." (quoting State v. Lomax, 608 P.2d 959, 967 (Kan. 1980))). Allowing sincere memory loss to be treated as "unavailability" for the purposes of hearsay exceptions expands the Kansas hearsay rule defining term, which does not specifically include lack of memory as a situation in which a witness is considered unavailable. See KAN. STAT. ANN. § 60-459(g) (1994). Hence, the Kansas court expanded the unavailability exception to make it more consistent with the Federal Rule, which includes lack of memory as a situation in which a witness is considered unavailable. See FED. R. EVID. 804(a)(3). The Federal Rules further provide that a witness who simply persists in refusing to testify is unavailable. See FED. R. EvID. 804(a)(2). This is not the law in Kansas. See State v. Johnson-Howell, 881 P.2d 1288, 1295-96 (Kan. 1994) (holding that a witness's refusal to testify did not make him an unavailable witness as defined by KAN. STAT. ANN. $§ 60-459(\mathrm{~g}))$.

57. See Todd, 954 P.2d at 5-7. The appellate court ruled that the trial court had incorrectly applied two of the hearsay exceptions (the present sense impression and statement of physical or mental conditions exceptions), but that the errors were harmless. See id. at 7. This points out a subsidiary issue with which prosecutors (and defendants alike) must deal: errors involving the admissibility of hearsay, or any other evidence, rarely result in a reversal. See Margaret A. Berger, When, If Ever, Does Evidentiary Error Constitute Reversible Error?, 25 LOY. L.A. L. REV. 893, 894 (1992) (finding only 30 out of 20,000 cases, during a two-year period, in which a court of appeals stated that its reversal was due to an evidentiary error).

58. 503 S.E.2d 563 (Ga. Ct. App. 1998).

59. See id. at 564.

60. See id. Georgia's res gestae exception is, generally speaking, the functional equivalent of an excited utterance, present sense impression, or state of mind exception. These exceptions grew out of the common law theory of res gestae, which, aside from its continuing use in Georgia, is now considered an antiquated concept. See 2 MCCORMICK ON EVIDENCE, supra note 2, § 


\section{Framing the Prosecution Problem}

The previous discussion of exceptions under which hearsay evidence has been allowed in domestic violence cases is not intended to be comprehensive. In any given case, the use of other exceptions will be defined by the potential evidence available, as well as the skill and creativity of the prosecutor. ${ }^{61}$ In many instances, however, the hearsay evidence will not fit within any of the established exceptions. If the statement does not fall under an established exception, but has "particularized guarantees of trustworthiness," a residual hearsay exception may accommodate the statement. ${ }^{62}$ If the statement does not have such guarantees of trustworthiness, however, or if the state does not have a residual exception, ${ }^{63}$ the hearsay statement is generally ruled inadmissible, and the prosecutor is in danger of losing what is possibly his most valuable evidence. As a result, the prosecution stands a greater chance of losing the case, a batterer may go free, and the victim's life may be further endangered. Further complicating matters is the fact that, in all contexts, appellate judges often decline to reverse a decision strictly on the basis of an incorrect hearsay ruling by the trial judge, finding the error harmless or the evidence cumulative. ${ }^{64}$ This factor makes it all the more critical that the correct judgment regarding the hearsay evidence be made at the trial level.

Perhaps the most well-known case involving such inadmissible hearsay evidence is the O.J. Simpson case. In his trial for murdering

268, at 196 ("The ancient phrase [res gestae] can be jettisoned ...."). The Georgia exception specifically states that "[d] eclarations accompanying an act, or so nearly connected therewith in time as to be free from all suspicion of device or afterthought, shall be admissible as part of the res gestae." GA. CODE ANN. § 24-3-3 (1995).

61. See Asmus et al., supra note 36, at 139 (arguing that "an affirmative, skilled use of the rules of evidence" can allow a jury to hear the facts of a case in which the victim is a reluctant or hostile witness).

62. Ohio v. Roberts, 448 U.S. 56, 66 (1980). Because the residual exception is not considered a "firmly rooted" exception for the purposes of the Confrontation Clause, see Idaho v. Wright, 497 U.S. 805, 817 (1990), the statement must have "particularized guarantees of trustworthiness." Roberts, 448 U.S. at 66. It is not immediately clear if this requirement necessitates a stronger showing of trustworthiness than the residual exception itself, which, under the Federal Rules of Evidence, requires "equivalent circumstantial guarantees of trustworthiness." FED. R. EVID. 807. See Part III.B.2 for a more complete analysis of Confrontation Clause issues.

63. Of the 41 states with codes of evidence generally paralleling the Federal Rules of Evidence, 14 do not have a residual exception for criminal cases. See 6 JACK B. WEINSTEIN \& Margaret Berger, Weinstein's Federal EVidence T-159 to T-162 (Joseph M. McLaughlin ed., 2d ed. 1997).

64. See, e.g., State v. Wood, 881 P.2d 1158, 1168-69 (Ariz. 1994) (en banc) (finding a "great deal" of admissible evidence proving that the defendant had acted with premeditation, despite the admission of some hearsay evidence); see also Berger supra note 57, at 894-95 (providing further examples of "harmless error" analysis). 
his ex-wife, Nicole Brown Simpson, and Ronald Goldman, the prosecution attempted to show that Simpson had a history of prior abuse of Nicole. Entries from Nicole's diary, however, and numerous other statements she had made describing the defendant's violence and threats, were ruled inadmissible hearsay. ${ }^{65}$ In determining that the statements did not fall within an established exception, Judge Lance Ito reflected on the powerful hearsay statements:

To the man or woman on the street, the relevance and probative value of such evidence is both obvious and compelling, especially those statements made just days before the homicide. It seems only just and right that a crime victim's own words be heard, especially in the court where the facts and circumstances of her demise are to be presented. However, the laws and appellate court decisions that must be applied by the trial court hold otherwise. ${ }^{66}$

The subsequent acquittal of O.J. Simpson-after nearly all of the evidence of prior domestic violence had been ruled inadmissible ${ }^{67}$-may be a perfect example of the problem faced by prosecutors. Without the hearsay evidence the prosecutors were unable to develop an important component of their case, and the jury was never given the opportunity to consider the magnitude of the prior abuse.

To address these issues, some jurisdictions have chosen to expand existing hearsay exceptions, ${ }^{68}$ while one jurisdiction, California, has adopted legislation to attempt to remedy this problem. ${ }^{69}$ The remainder of this Note evaluates these attempted solutions, discusses the arguments for, and barriers to, a legislative solution, and, finally, considers the elements of such an exception that would be required for fairness.

\section{THE EXPANSION OF EXISTING HEARSAY EXCEPTIONS IN DOMESTIC VIOLENCE CASES}

The approach taken by some jurisdictions to remedy the prosecution problem described in Part I is to expand the meaning of existing hearsay exceptions. Simply expanding the existing exceptions and

65. See Ruling, People v. Simpson, No. BA097211, 1995 WL 21768, at*5-*7 (Cal. Super. Ct. Jan. 18, 1995).

66. Id. at $* 5$.

67. See id. (admitting only a 911 tape and not admitting other statements indicating domestic violence as inadmissible hearsay).

68. See infra Part II.

69. See infra Part III.C. 
exclusions beyond their conventional meaning, however, threatens to erode the integrity of the hearsay rule.

\section{A. Hearsay Exceptions and Exclusions Subject to Expansion}

To some extent, all hearsay exceptions and exclusions are susceptible to expansion. The following examples highlight the practice of some jurisdictions with respect to particular exceptions. These examples are not intended to constitute a comprehensive list, but rather to offer a reflection of this approach and its pitfalls.

1. The State of Mind Exception. ${ }^{70}$ A prosecutor is interested in establishing facts that would lead a jury to conclude that the defendant committed a particular crime. Although a victim's description of her state of mind is admissible as an exception to the hearsay rule, ${ }^{71}$ the exception excludes statements of memory or belief that introduce underlying facts serving as the basis for the victim's state of mind. Unfortunately for prosecutors in domestic violence cases, these facts are precisely the information in which they are most interested. Thus, there may be a tendency to try to introduce more than just the state of mind or, at the very least, to create an inference of the underlying facts. However, the restriction of statements of memory or belief is well grounded, as indicated in the Federal Rules of Evidence. ${ }^{72}$ To permit a statement of memory or belief into evidence would threaten to swallow up the hearsay rule by "allowing state of mind, provable by a hearsay statement, to serve as the basis for an inference of the happening of the event which produced the state of mind." ${ }^{, 73}$

70. See, e.g., FED. R. EVID. 803(3) (excepting from the hearsay rule statements of the declarant's "then existing state of mind, emotion, sensation, or physical condition (such as intent, plan, motive, design, mental feeling, pain, and bodily health), but not including a statement of memory or belief to prove the fact remembered or believed," unless the terms of a will are in dispute). State rules of evidence are generally equivalent. See 6 WEINSTEIN \& BERGER, supra note 63 , at T-113 to T-116.

71. The relevance of state of mind evidence, as well as a balancing of probativity versus prejudicial impact, must still be considered prior to admissibility. See FED. R. EVID. 401-03; 1 MCCORMICK ON EVIDENCE, supra note 2, §§ 184-85, at 636-48.

72. The Federal Rules specifically exclude statements of memory or belief from being excepted from the hearsay rule. See FED. R. EVID. 803(3); see also 2 MCCORMICK ON EVIDENCE, supra note $2, \S 276$, at 227-32 (discussing generally the exclusion of such statements).

73. FED. R. EvID. 803(3) advisory committee's note; see also Shepard v. United States, 290 U.S. 96, 105-06 (1933) ("Declarations of intention, casting light upon the future, have been sharply distinguished from declarations of memory, pointing backwards to the past. There would be an end, or nearly that, to the rule against hearsay if the distinction were ignored."). 
In some jurisdictions, however, this aspect of the rule is essentially ignored. ${ }^{74}$ For instance, the language of the North Carolina state of mind exception is identical to the Federal Rule, ${ }^{75}$ yet the North Carolina courts limit the restriction of statements of memory or belief to statements that relate only factual events. ${ }^{76}$ If the facts contained in the victim's statement serve to demonstrate the basis for her state of mind, the statements relating factual events are not excluded. ${ }^{77}$ For example, in State v. Scott, ${ }^{78}$ the victim's statements that the defendant had caused her injuries in the past and that she was afraid of the defendant were admitted under the state of mind exception. ${ }^{79}$

Similarly, in a Tennessee case, the victim's statement to her boyfriend that she did not want him to come by her house because she was afraid that his being there would cause a conflict with her estranged husband was ruled admissible under the state of mind exception. $^{80}$ Although the trial court admitted the statement because it felt that the statement was merely cumulative, ${ }^{81}$ the Tennessee Supreme Court admitted the statement explicitly under the state of mind exception and stated that it was relevant to show the victim's plans and to explain why she did not see her boyfriend that day. ${ }^{82}$ The court acknowledged that the statement could be used improperly, i.e., to establish the defendant's conduct, but indicated that, because the record included other testimony that the defendant and the victim were together that particular day, the potentially improper use was not determinative. ${ }^{83}$ Although the evidence may have been cumulative to

74. Jurisdictions which allow statements of memory to be admissible under the state of mind exception in domestic violence cases will often do so in other cases as well. For example, the North Carolina courts expand the state of mind exception in domestic violence homicide cases to admit facts that serve as the basis of the declarant's state of mind. See infra notes 75-79 and accompanying text. This expansion is equally applicable to non-domestic violence cases. See, e.g., State v. Bishop, 488 S.E.2d 769, 776-77 (N.C. 1997) (expanding the state of mind exception in a case involving a defendant who had handled real estate and horse sales for the victim); State v. Miller, 477 S.E.2d 915, 925-26 (N.C. 1996) (expanding the state of mind exception in a case involving a defendant who was the next-door neighbor of the victim).

75. See N.C. R. EvID. 803(3).

76. See State v. Hardy, 451 S.E.2d 600, 612 (N.C. 1994); State v. Hayes, 502 S.E.2d 853, 866 (N.C. Ct. App. 1998).

77. See State v. Gray, 491 S.E.2d 538, 550 (N.C. 1997); Hayes, 502 S.E.2d at 866.

78. 471 S.E.2d 605 (N.C. 1996).

79. See id. at 618 .

80. See State v. Smith, 868 S.W.2d 561, 574-75 (Tenn. 1994).

81. See id. at 574 ("The trial court admitted the hearsay apparently because it had to do with matters that we've already considered." (citation and internal quotation marks omitted)).

82. See id.

83. See id. at $574-75$. 
show the location of the defendant that day, the more damaging part of the victim's statement was her fear of a possible conflict and of violence on the part of the defendant. These statements are precisely what the exception aims to exclude. Accordingly, the statement should not have been admitted into evidence based on the Tennessee Rules of Evidence. ${ }^{84}$ Although other evidence on this issue may have been available in the record, the court does not indicate this fact in the immediate discussion. If this was the case, a more appropriate ruling would have been for the appellate court to hold that the statement was erroneously admitted, but that the error was harmless.

In domestic violence cases, the state of mind exception is also commonly used to demonstrate the victim's fear of the defendant. ${ }^{85}$ While fear is an expression of a victim's state of mind, jurisdictions are split as to whether it is relevant and admissible. Some jurisdictions follow a narrow interpretation of the exception, noting that a victim's fear has no bearing on proving the defendant's motive and that state of mind evidence should not be used to prove the conduct of the defendant. ${ }^{86}$ Other jurisdictions, however, have expanded the exception and held that the fear of the victim is relevant to show the defendant's motive. $^{87}$

84. See TenN. R. Evid. 803(3). The Tennessee rule is identical to the Federal Rule. See supra notes $72-73$.

85. See Donna Meredith Matthews, Making the Crucial Connection: A Proposed Threat Hearsay Exception, 27 GOLDEN GATE U. L. REV. 117, 142 (1997) (indicating that when the victim's state of mind is an issue most courts admit expressions of fear).

86. See, e.g., People v. Noguera, 842 P.2d 1160, 1171 (Cal. 1992) ("[H]earsay statements of victims concerning fears of or threats against them by the accused, when offered to prove the conduct of the accused, are not within the [state of mind] exception to the hearsay rule ...."); State v. Duntz, 613 A.2d 224, 237 (Conn. 1992) (holding that statements of the victim's fear of the defendant were not relevant to establishing the defendant's motive and thus were not admissible under the state of mind exception to the hearsay rule); Banks v. State, 608 A.2d 1249, 1254 (Md. Ct. Spec. App. 1992) (holding that neither fear of the defendant nor conflict avoidance "has any legal significance in establishing the elements of murder or manslaughter"); Commonwealth v. McGraw, 690 N.E.2d 400, 404 (Mass. 1998) (holding that "evidence of a victim's fear of the defendant is not admissible at all to prove motive").

87. See, e.g., State v. Wood, 881 P.2d 1158, 1167-68 (Ariz. 1994) (en banc) (holding that the victim's statements of fear and of a desire to end the relationship helped to explain the defendant's motive, a disputed issue at trial, and that they were therefore admissible); State v. Alston, 298 S.E.2d 631, 637 (N.C. 1983) (holding that "the use of statements of the victim tending to show ill will between the defendant and the victim must be carefully scrutinized," but that they can be admissible "to show premeditation and deliberation, motive and intent"); Moore v. State, 761 P.2d 866, 870 (Okla. Crim. App. 1988) (holding that statements reflecting the victim's fear of the defendant were admissible under the state of mind exception because they provided a motive for the killing). 
2. The Prior Inconsistent Statement Exclusion. ${ }^{88}$ Another questionable instance in which some courts are admitting hearsay involves the prior inconsistent statement. Although prior inconsistent statements may generally be used for impeachment purposes ${ }^{89}$ the Federal Rules also permit a prior inconsistent statement of a witness to be used substantively, thereby excluding it from the hearsay rule, if it was given under oath at an official proceeding or deposition. ${ }^{90}$

Seemingly, this hearsay exclusion would be very useful in situations in which the victim recants an earlier statement, but its application is restricted by the Federal Rule requirement that the out-ofcourt statement be made under oath at an official proceeding or deposition. For example, in the Federal Rules, the exclusion is not generally read to extend to statements given to police officers at the police station or immediately following an incident; ${ }^{91}$ such statements would be considered hearsay. The rationale behind this Federal Rule is that an investigative interrogation by the police is "neither regulated nor regularized [and] contains none of the safeguards involved in an appearance before a grand jury. ${ }^{, 92}$

However, some states, such as Connecticut, have permitted prior inconsistent statements to be used substantively in such situations. In one instance, the court allowed a sworn, written statement that was made by the victim to the police (but not in any formal proceeding) and that described the plaintiff's physical abuse to be admitted substantively as a prior inconsistent statement after the victim denied the statement at trial. ${ }^{93}$ Connecticut allows prior inconsistent statements if

88. See, e.g., FED. R. EVID. 801(d)(1)(A):

A statement is not hearsay if ... [ $\mathrm{t}]$ he declarant testifies at the trial or hearing and is subject to cross-examination concerning the statement, and the statement is ... inconsistent with the declarant's testimony, and was given under oath subject to the penalty of perjury at a trial, hearing, or other proceeding, or in a deposition ....

89. See id. 613(b); 1 MCCORMICK ON EvIDENCE, supra note 2, § 34, at 126 :

The attack by prior inconsistent statement is not based on the theory that the present testimony is false and the former statement true but rather upon the notion that talking one way on the stand and another way previously is blowing hot and cold, raising a doubt as to the truthfulness of both statements.

90. See Fed. R. Evid. 801(d)(1)(A).

91. See James E. Beaver, The Residual Hearsay Exception Reconsidered, 20 FLA. ST. U. L. REV. 787, 819 \& n.278 (1993) (stating that, for the purposes of the prior inconsistent statement exclusion, there is "substantial authority that no variation of police investigative activity constitutes a proceeding," and citing sources). Of course, if a statement meets the criteria of another hearsay exclusion (such as an admission) or exception (such as an excited utterance), it may still be admissible as evidence.

92. Delgado-Santos v. State, 471 So. 2 d 74, 78 (Fla. Dist. Ct. App. 1985).

93. See State v. Borrelli, 629 A.2d 1105, 1108 (Conn. 1993). 
a three-part test is met: (1) the declarant signed the statement, (2) the declarant had personal knowledge of the facts set forth in the statement, and (3) the declarant testified at trial and was subject to crossexamination. ${ }^{94}$ Connecticut courts have reasoned that a "statement made under circumstances providing a reasonable assurance of reliability should be admitted to advance the truth finding function of the jury." 95

Similarly, Hawaii, in its formal evidence code, broadens the prior inconsistent statement exception by allowing the substantive use of prior written statements signed by a witness ${ }^{96}$ as well as those given in formal proceedings. ${ }^{97}$ Hawaii also allows as a prior statement taperecordings made contemporaneously with the making of the statement. ${ }^{98}$ This exception enabled the prosecutors in State $v$. Clark, ${ }^{99}$ the case discussed in the Introduction, ${ }^{100}$ to use the tape-recorded statement given by the victim to the investigating officer. However, the concerns discussed previously regarding statements given to police also apply to tape-recorded statements. ${ }^{10}$

Additionally, the genesis of the language used in the Hawaii rule raises questions. The language allowing written and tape-recorded statements was taken from the federal Jencks Act, ${ }^{102}$ a federal law that governs the production or discovery of written or recorded statements made to government agents by government witnesses. ${ }^{103}$ The Jencks Act, however, has been interpreted as restricting the use of such statements to impeachment only. ${ }^{104}$ Applying the same language to statements that would be used substantively is, therefore, an expansion of the prior inconsistent statement rule.

94. See id. at 1108 (citing State v. Whelan, 513 A.2d 86, 92 (Conn. 1986)).

95. Id.; see also Whelan, 513 A.2d at 93 \& n.10 (expressing concern over the untrustworthiness of some prior inconsistent statements, but deciding that limiting substantive admissibility only to statements made in a formal adversarial setting is unnecessary).

96. See HAw. R. Evid. 802.1(1)(B); see also State v. Tomas, 933 P.2d 90, $94-95$ (Haw. Ct. App. 1997) (applying HAW. R. EVID. 802.1(1)(B)).

97. See HAW. R. EvID. 802.1(1)(A) (admitting prior inconsistent statements "[g]iven under oath ... at a trial, hearing, or other proceeding, or in a deposition").

98. See id. $802.1(1)(\mathrm{C})$.

99. 926 P.2d 194 (Haw. 1996).

100. See supra notes 1-7 and accompanying text.

101. While a tape-recorded statement played in court would certainly provide a guarantee of accuracy, other concerns underlying the normal inadmissibility of police interviews, such as a lack of formality, a lack of oath, and the potential for coercion, may still be present, making the ultimate reliability of the recording questionable. See supra notes 91-92 and accompanying text.

102. See HAW. R. EvID. 802.1 commentary.

103. See 18 U.S.C. $\$ 3500$ (1994).

104. See Palermo v. United States, 360 U.S. 343, 349 (1959). 
3. The Recorded Recollection Exception. ${ }^{105}$ A Vermont court took a relatively unique approach to the hearsay problem in domestic violence cases by admitting a prior tape-recorded statement of the victim after she claimed, at trial, that she could not remember the domestic violence. ${ }^{106}$ As part of his investigation, the police officer tape-recorded an interview with the victim the day after the assault. ${ }^{107}$ The prosecutor was successful in admitting this tape-recorded interview under the recorded recollection exception. ${ }^{108}$ To be admissible under this exception, the evidence must meet three requirements: (1) the record must pertain to matters about which the declarant once had knowledge, (2) the declarant must have present insufficient memory, and (3) the record must be shown to have been made by the declarant or, if made by someone else, to have been examined by the declarant and shown to reflect accurately the declarant's knowledge when the matters were fresh in the declarant's memory. ${ }^{109}$ In affirming the trial court, the Vermont Supreme Court held that the first two requirements were easily met ${ }^{110}$-although there is some question as to whether the court truly believed that the declarant had present insufficient memory-and that her claimed memory lapse was not just a subterfuge for recantation. ${ }^{111}$ After an extended discussion, the court held that the third requirement was also met, noting that there was no question that the victim had given the tape-recorded statement and that evidence presented by the state was sufficient to show that the statement accurately reflected the knowledge of the victim. ${ }^{112}$

105. See, e.g., FED. R. EVID. 803(5) (excepting from the hearsay rule a "memorandum or record concerning a matter about which a witness once had knowledge but now has insufficient recollection to enable the witness to testify fully and accurately, shown to have been made or adopted by the witness when the matter was fresh in the witness' memory and to reflect that knowledge correctly"); 2 MCCORMICK ON EVIDENCE, supra note 2, §§ 279-83, at 240-47 (discussing the exception for records of past recollection).

106. See State v. Marcy, 680 A.2d 76 (Vt. 1996).

107. See id. at 77.

108. See id. at 78 (relying on VT. R. EvID. 803(5)). The Vermont Rule is substantively identical to the Federal Rule. See supra note 105.

109. See Marcy, 680 A.2d at 78 (citing State v. Paquette, 497 A.2d 358, 360 (Vt. 1985)).

110. See id. (finding that "[a]s the victim of the assault, the witness once had knowledge of it, and her tape-recorded statement relates that knowledge in detail" and noting that the trial court found that it was "clear and without question[] that the declarant now has insufficient recollection about any matters contained in that tape or ... concern[ing] what did or did not happen to her on [the date of the assault]'").

111. See id. at 83 (Dooley, J., dissenting) ("The reality is that both the trial judge and the majority believe that this is a case of recantation by convenient memory lapse. That is, they are skeptical of the victim's assertion that she remembers neither the assault nor the statement."). 


\section{B. Implications of the Expansion of Existing Hearsay Exceptions}

Hearsay exceptions may be particularly susceptible to expansion in domestic violence cases because there is a strong social policy interest in reducing domestic violence and because the victim's own words seem so "obvious and compelling." "113 However, the expansion of hearsay exceptions has implications for the broad use of the hearsay rule.

As discussed in Section III.A.1, a strong social policy argument can be made for admitting hearsay in domestic violence cases. The private nature of domestic violence, in which only the victim and the perpetrator have firsthand knowledge of the incident, makes the need to use hearsay significant. At the same time, we must recognize that expanding existing hearsay exceptions would have a significant impact on non-domestic violence cases. For example, by expanding the state of mind exception in a domestic violence case, the door may be opened in another, non-domestic violence case, where the policy arguments and the need to use hearsay are not nearly as strong. The elastic nature of the common law system may allow the interpretation of these exceptions in domestic violence cases to carry precedential value in cases in which there is little or no social policy justification, or necessity, for admitting the hearsay.

Perhaps the only alternative to expanding existing hearsay exceptions would be to create a new hearsay exception for use only in the domestic violence context. The arguments for creating such an exception, as well as the potential barriers to an exception, are discussed in the following section.

\section{A Legislative Solution? Towards A HeARSAy EXCEPTION FOR DOMESTIC VIOLENCE}

As discussed in the previous section, the practice of expanding existing exceptions in order to admit hearsay in domestic violence cases is not the best solution. If the use of hearsay statements in domestic violence cases is to be permitted, it would be more appropriate to create a new hearsay exception confined to the domestic violence

112. See id. at 79 (detailing the trial court's findings that the victim was coherent and responsive when she made the statement and that the statement was made within a day of the assault, that it was consistent with a prior interview, that it related the details of the assault chronologically, that it was corroborated by other witnesses, and that it was never recanted).

113. People v. Simpson, No. BA097211, 1995 WL 21768, at*5 (Cal. Super. Ct. Jan. 18, 1995). 
context. Such an exception would be tailored to serve the dual purpose of meeting the needs of domestic violence prosecutors and of ensuring fairness and constitutional protections for the defendant.

\section{A. Arguments for a Hearsay Exception for Domestic Violence}

A new hearsay exception for domestic violence is an appropriate solution for two primary reasons. First, there is a strong social policy interest in reducing domestic violence: a hearsay exception for domestic violence situations would assist prosecutors in bringing domestic violence perpetrators to justice. ${ }^{114}$ Second, a number of existing evidence rules have been created primarily in response to policy concerns, not necessarily grounded in the theoretical underpinnings of evidence rules. ${ }^{115}$ Thus, even though a proposed hearsay exception for domestic violence is driven by policy and does not fit fully within the evidence rules' theoretical framework, it would be a suitable candidate for legislative action.

1. The Social Policy Argument. As described previously, ${ }^{116}$ domestic violence is a very significant societal, as well as individual, problem that the criminal justice system needs resources to combat. The ability of the criminal justice system to do so is complicated by the fact that most domestic violence assaults usually take place in private, where only the abuser and the abused know with certainty what has occurred. ${ }^{117}$ Although the victim, immediately after the incident, may make statements to police investigators or others about what has happened, ${ }^{118}$ she is often unavailable, or unwilling, to testify at trial. ${ }^{119}$ Thus, her story is often left untold. ${ }^{120}$ In many situations, the prosecution of domestic violence cases can only be effective if the hearsay statements of the victim are admissible at trial. A new

\footnotetext{
114. See infra Part III.A.1.

115. See infra Part III.A.2.

116. See supra notes 10-24 and accompanying text.

117. Assaults may often be witnessed by children, see Wills, supra note 17 , at 175 , but children may often be incapable of testifying at a trial, for a variety of reasons. See supra note 19.

118. See, e.g., State v. Clark, 926 P.2d 194, 202-03 (Haw. 1996); State v. Campbell, 539 N.W.2d 491, 493 (Iowa 1995).

119. See supra Part I.

120. See Matthews, supra note 85, at 118-19 (pointing out that in many domestic homicide cases the victim's "only witness is herself, and she is dead"); Raeder, supra note 10, at 1469 ("[E]ven in death the criminal justice system may not let the voice of the battered victim tell her story ....."); see also supra Part I (discussing this prosecution problem).
} 
hearsay exception, covering these situations would allow the full story to be told. ${ }^{121}$

2. Precedence in Existing Rules of Evidence. A number of existing rules of evidence have been implemented primarily for policy purposes. A clear example of this phenomenon is Rule 413 of the Federal Rules of Evidence, which relates to the use of evidence of similar crimes in sexual assault prosecutions. ${ }^{122}$ The general rule, established by the Federal Rules, is that evidence of "other crimes, wrongs, or acts is not admissible to prove the character of a person in order to show action in conformity therewith," 123 although such evidence may be admissible for other purposes, such as proof of motive. ${ }^{124}$ Rule 413 , however, specifically allows evidence of a prior sexual assault, and such evidence "may be considered for its bearing on any matter to which it is relevant." ${ }^{125}$ Thus, this rule is an exception to the general rule previously established. In adopting this rule, Congress ignored, and deliberately bypassed, the strong opposition of the Judicial Conference, the body authorized by Congress to promulgate new rules of evidence. ${ }^{126}$ Congress justified its decision by noting both the difficulty in successfully prosecuting rape cases and the perception that current law is disproportionately favorable to the defendant in sexual assault prosecutions. These difficulties, Congress concluded, led to too many rape prosecutions that resulted in acquittals or reversals on appeal. ${ }^{127}$

121. In jurisdictions that currently expand existing exceptions, the full story is often able to be told. Thus, a new hearsay exception would not necessarily provide the same impact in such a jurisdiction as in a jurisdiction that does not expand existing exceptions. However, as this Note argues, a new exception is a more appropriate tool for prosecutors than expansion of existing exceptions.

122. See FED. R. EvID. 413 (admitting certain evidence of similar crimes in sexual assault cases). The same policies underlying the passage of Rule 413 apply to Rules 414 and 415 , which were adopted at the same time. See id. 414 (admitting certain evidence of similar crimes in child molestation cases); id. 415 (admitting certain evidence of similar acts in civil cases concerning sexual assault or child molestation).

123. Id. 404(b).

124. See id.

125. Id. 413(a) (emphasis added).

126. See Michael S. Ellis, Comment, The Politics Behind Federal Rules of Evidence 413, 414, and 415, 38 SANTA Clara L. Rev. 961, 971-72 (1998); Debra Sherman Tedeschi, Comment, Federal Rule of Evidence 413: Redistributing “The Credibility Quotient”, 57 U. PITT. L. REV. 107, 119-20 (1995).

127. See Mary Katherine Danna, Note, The New Federal Rules of Evidence 413-415: The Prejudice of Politics or Just Plain Common Sense?, 41 ST. LOUIS U. L.J. 277, 291 (1996) (listing congressional justifications for Rules 413-15). Several commentators have correlated the heightened attention given to sexual assault prosecutions at that time with the highly publicized date 
Many states have adopted a similarly policy-based hearsay exception for statements made by victims of child sexual abuse. ${ }^{128}$ These exceptions have arisen from a set of broad factual determinations and policy judgments, ${ }^{129}$ many of which are also present in domestic violence cases: the sexual assaults often occur in the home, with few witnesses, and the child's out-of-court statements are sometimes the most important, or only, evidence available to prove abuse. ${ }^{130}$ The child may also be unwilling, or unable, to testify for a variety of reasons, including fear of reprisal by the abuser, guilt, age, and capacity. ${ }^{131}$ Other justifications for the child sexual abuse exception are the inherent reliability of the statements ${ }^{132}$ and the belief that children may be harmed by the trial process. ${ }^{133}$

The co-conspirator exclusion to the hearsay rule ${ }^{134}$ is also founded on policy. Under this provision, a statement is not hearsay if it is "offered against a party and is ... a statement by a coconspirator of a party during the course and in furtherance of the conspiracy." 135 Reliability plays a distinctly secondary role. Rather, the "need for this evidence, which was particularly valuable in prosecuting a conspiracy, permitted a somewhat reduced concern for the reliability of the statement." ${ }^{136}$ Thus, existing rules of evidence provide precedent for

rape trial of William Kennedy Smith. See Sara Sun Beale, Prior Similar Acts in Prosecutions for Rape and Child Sex Abuse, 4 CRIM. L.F. 307, 307-08 (1993); Danna, supra, at 289; Ellis, supra note 126 , at 974 .

128. See, e.g., Colo. Rev. STAt. § 13-25-129 (1999); KAn. STAT. AnN. § 60-460(dd) (1994); Or. Rev. STAT. § 40.460(18a)(b) (Supp. 1998); Utah Code AnN. § 76-5-411 (1999). The Federal Rules have not adopted this exception.

129. See Robert P. Mosteller, Remaking Confrontation Clause and Hearsay Doctrine Under the Challenge of Child Sexual Abuse Prosecutions, 1993 U. ILL. L. REV. 691, 695 (1993) (describing the policy judgments behind the hearsay exceptions in child sexual abuse cases).

130. See id.; Jean L. Kelly, Comment, Legislative Responses to Child Sexual Abuse Cases: The Hearsay Exception and the Videotape Deposition, 34 CATH. U. L. REV. 1021, 1024 (1985).

131. See Mosteller, supra note 129, at 695; Kelly, supra note 130, at 1024.

132. See Mosteller, supra note 129, at 695 (noting that children will rarely lie to authority figures about sexual activity and that most children do not have sufficient knowledge about sexual functioning to lie effectively).

133. See id. (pointing out that "although not universally true, in-court testimony by a child may produce emotional and psychological trauma that in some instances will be long-lasting").

134. See FED. R. Evid. 801(d)(2)(E); 2 MCCORMICK ON EvIDENCE, supra note 2, § 259, at

$156-60$ (discussing the co-conspirator exclusion).

135. FED. R. EVID. 801(d)(2)(E).

136. Bourjaily v. United States, 483 U.S. 171, 190 (1987) (Blackmun, J., dissenting). Justice Blackmun also noted that, despite limited guarantees of trustworthiness, see id. at 191, courts have justified the admission of a co-conspirator's hearsay statements by arguing that a "party could not complain of the deprivation of the right to cross-examine himself ... or to advocate his own, or his agent's, untrustworthiness," id. at 190. See also Raeder, supra note 10, at 1512 (questioning why a similar need-based exception never arose for domestic abuse threats in mur- 
the creation of rules with an eye toward policy and of hearsay exceptions based primarily on need, as opposed to reliability. ${ }^{137}$

\section{B. Obstacles to a Hearsay Exception for Domestic Violence}

Although there are strong arguments for creating a new exception to the hearsay rule for domestic violence, obstacles exist. These hurdles arise from the traditional concerns relating to hearsay exceptions-confrontation, corresponding trustworthiness guarantees, and necessity-but, in the end, they boil down to the need to preserve an accused's right to a fair trial.

1. Confrontation. The Confrontation Clause of the Sixth Amendment requires that "[i]n all criminal prosecutions, the accused shall enjoy the right... to be confronted with the witnesses against him." 138 There are numerous exceptions to the Confrontation Clause, and, through a series of decisions, the Supreme Court has provided guidance for the application of the Confrontation Clause to hearsay statements. ${ }^{139}$ In Ohio v. Roberts,${ }^{140}$ the Court set out a two-part test for admitting hearsay evidence when the Confrontation Clause is implicated. First, hearsay evidence may be introduced only when the declarant is produced or the unavailability of the declarant is demonstrated. ${ }^{141}$ Second, the statement must have been made under circumstances providing sufficient "indicia of reliability." ${ }^{142}$ The Court held further that a statement falling under a "firmly rooted hearsay exception" is sufficiently reliable. ${ }^{143}$ If the evidence does not fall within such an exception, "particularized guarantees of trustworthiness are required for admission." "144 The Court has since backed away from the unavailability requirement, and, at present, unavailability of the declarant is required only when the particular hearsay exception requires it. ${ }^{145}$

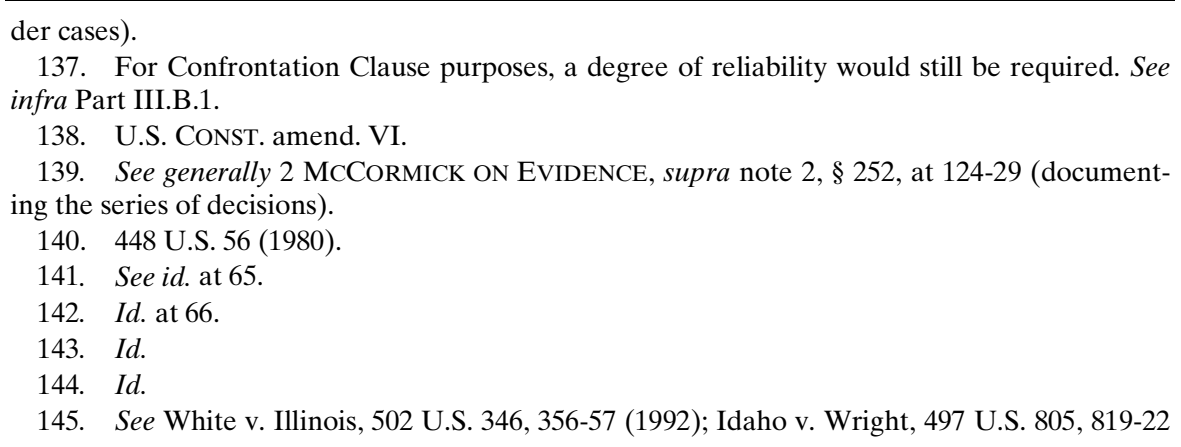


In subsequent decisions, the Court has provided additional guidance for statements that do not fall into a "firmly rooted exception." In Idaho v. Wright, ${ }^{146}$ the Court instructed that the guarantees of trustworthiness reflect the "totality of the circumstances that surround the making of the statement and that render the declarant particularly worthy of belief." ${ }^{147}$ The Court also specifically rejected the use of corroborative evidence, stating that the hearsay evidence "must possess indicia of reliability by virtue of its inherent trustworthiness, not by reference to other evidence at trial." 148

Any new exception to the hearsay rule will clearly not be a "firmly rooted" exception under Roberts. Therefore, a hearsay statement admitted under the exception must have "particularized guarantees of trustworthiness." Other evidence of domestic violence, while relevant to the case, also could not be used to support the introduction of a hearsay statement admitted under a newly created domestic violence exception. The statement must be able to stand the test of trustworthiness on its own. While this obstacle is not impossible to overcome, it provides a much larger hurdle and could severely restrict the applicability of a new exception.

2. Trustworthiness Guarantees. Because a new exception would not be "firmly rooted," current Confrontation Clause interpretation requires that a statement have "particularized guarantees of trustworthiness." In-court witnesses are subject to three conditions that provide such a guarantee of trustworthiness: oath, personal presence, and cross-examination. ${ }^{149}$ These elements are not present for the declarant of a hearsay statement. As such, other guarantees of trustworthiness are required. For example, the reliability of the excited utterance exception is guaranteed because excitement "temporarily stills the capacity of reflection and produces utterances free of conscious fabrication." 150 Similarly, the reliability of the medical diagnosis exception is founded on the strong motivation of

\footnotetext{
(1990); United States v. Inadi, 475 U.S. 387, 391-400 (1986); see also 2 MCCORMICK ON EVIDENCE, supra note 2, § 252, at 124.

146. 497 U.S. 805 (1990).

147. Id. at 820 .

148. Id. at 822 .

149. See 2 MCCORMICK ON EVIDENCE, supra note 2, § 245, at 93.

150. FED. R. EVID. 803(2) advisory committee's note; see also 2 MCCORMICK ON EVIDENCE, supra note $2, \S 272$, at 204-05 (discussing the rationale of the exception).
} 
the patient to provide truthful information for purposes of medical treatment. ${ }^{151}$

In the domestic violence context, hearsay statements not falling under an existing exception may not have particularized guarantees of trustworthiness. When, for example, the victim of domestic violence tells her story to the police, the victim is usually not under oath, the jurors cannot observe the demeanor of the victim when she makes the statement, and the defense counsel cannot cross-examine the victim. Thus, a new exception would have to include some requirement that would help to guarantee trustworthiness. One potential requirement is the use of videotape. Presentation of the videotape at trial could act as a partial substitute for personal presence. A videotaped statement could also be made under oath, which would provide an additional factor in determining reliability. The potential applicability of a videotape requirement, as well as general requirements for trustworthiness in a new exception, are discussed in Section IV.C.

3. Necessity. Although trustworthiness guarantees are a necessary component of a new hearsay exception, the need to permit hearsay statements can provide additional support for the creation of an exception. Without a necessity basis, a new exception would be much more difficult to justify.

Necessity plays a role in several hearsay exceptions, particularly those in which unavailability is a requirement. Statements falling within a hearsay exception for which unavailability is required ${ }^{152}$ are recognized as being less reliable than in-court testimony. ${ }^{153}$ However, because the admission of hearsay evidence is preferred to losing the evidence of the declarant entirely, ${ }^{154}$ courts may admit hearsay, subject to other evidentiary considerations such as relevance.

Other exceptions and exclusions also have foundations in necessity. The assurance of the reliability of the state of mind exception, for

151. See FED. R. EvID. 803(4) advisory committee's note; 2 MCCORMICK ON EVIDENCE, supra note $2, \S 277$, at 233 (discussing the reliability of this exception).

152. See FED. R. EVID. 804 (defining "[u]navailability as a witness").

153. See id. 804(b) advisory committee's note (preferring live testimony over hearsay); 3 Stephen A. SAltzburg et AL., Federal Rules OF Evidence Manual 1829 (7th ed. 1998) (noting that statements falling within the unavailability exception are not as reliable as in-court testimony).

154. See FED. R. EvID. 804(b) advisory committee's note (preferring hearsay over the complete loss of the evidence); 2 MCCORMICK ON EVIDENCE, supra note 2, § 253, at 126-31 (discussing hearsay exceptions where the declarant is unavailable); 3 SALTZBURG ET AL., supra note 153 , at 1829 (recognizing that "statements are better than no evidence at all"). 
example, rests on the spontaneity and apparent sincerity of the statements. ${ }^{155}$ However, the exception does not explicitly require trustworthiness, and the declarant could conceivably fabricate his state of mind. ${ }^{156} \mathrm{~A}$ necessity basis-that the individual has a unique perspective on his own state of mind and, therefore, that no better way exists to prove state of mind than through the individual's statements ${ }^{157}$ strengthens the rationale for the state of mind exception. Similarly, the co-conspirator exclusion ${ }^{158}$ and the child sexual abuse exception ${ }^{159}$ also have a strong foundation in the necessity of the statement, as opposed to, or in addition to, trustworthiness guarantees.

Domestic violence victims are often unavailable, either voluntarily or involuntarily. ${ }^{160}$ Additionally, as with child sexual abuse cases, ${ }^{161}$ the victims are frequently the only source of information regarding the assault, and they are often unwilling to testify. ${ }^{162}$ The need for the hearsay statements is itself sufficient to warrant the creation of a new exception. ${ }^{163}$ However, to be fair to the defendant and to comply with the Confrontation Clause, such an exception must also have guarantees of trustworthiness.

Furthermore, it is often the case that a victim will refuse to testify or to recant an earlier story out of fear of physical or economic reprisals from the batterer. ${ }^{164}$ Threats by the batterer, if proved, could be grounds for using a forfeiture by wrongdoing exception-such as that recently included in the Federal Rules ${ }^{165}$ - which is designed to pre-

155. See 2 MCCORMICK ON EVIDENCE, supra note 2, § 274, at 217; 3 SALTZBURG ET AL., supra note 153 , at 1656 .

156. See 3 SALTZBURG ET AL., supra note 153 , at 1661.

157. See 2 MCCORMICK ON EVIDENCE, supra note 2, § 274, at 217-18; 3 SALTZBURG ET AL., supra note 153 , at 1656 .

158. See supra notes 134-36 and accompanying text.

159. See supra notes 128-33 and accompanying text.

160. See supra Part I.

161. See supra notes 129-31 and accompanying text.

162. See supra notes 19-24 and accompanying text.

163. Cf. Raeder, supra note 10, at 1512-13 (suggesting that a "[1]ack of sensitivity to the problem of proof in domestic femicide cases" may explain why an exception has not been created for domestic abuse threats, even though a similar problem of proof was a significant factor in leading to the creation of the co-conspirator exclusion).

164. See supra notes $43-44$ and accompanying text.

165. The Federal Rules of Evidence provide that, if the declarant is unavailable as a witness, a statement is not excluded by the hearsay rule if the statement was "offered against a party that has engaged or acquiesced in wrongdoing that was intended to, and did, procure the unavailability of the declarant as a witness." FED. R. EVID. 804(b)(6). This exception was added to the Federal Rules in 1997. See id. advisory committee's note. 
vent witness tampering. ${ }^{166}$ The problem is that, in order for the exception to apply, witness tampering must be shown by a preponderance of the evidence. ${ }^{167}$ Because, in most situations, the prosecution could show only the possibility that the victim is reluctant to testify because of fear of the defendant, this exception would be difficult to apply. Thus, the problem of proof for this exception underscores the need for a new exception.

\section{The California Example}

In 1996, the California legislature took these concerns into account and enacted a new hearsay exception that allows admission of hearsay statements that explain the infliction or threat of physical injury upon the declarant. ${ }^{168}$ This exception was passed in the wake of the O.J. Simpson murder trial, ${ }^{169}$ in which Nicole Brown Simpson's diaries and other statements of threats and violence were ruled inadmissible. ${ }^{170}$

Under section 1370, a hearsay statement may be admissible ${ }^{171}$ if several conditions are met. First, the statement must purport to "narrate, describe, or explain the infliction or threat of physical injury upon the declarant." ${ }^{172}$ This condition would include statements describing the infliction of the injury that is the subject of the case, as well as past incidents of violence or threats. These statements of memory are explicitly not protected by the existing state of mind exception in the Federal Rules, ${ }^{173}$ but, for this new California exception,

166. See id. ("[The rule] applies to actions taken after the event to prevent a witness from testifying."); Raeder, supra note 10, at 1515 ("When the defendant's actions amount to witness tampering, it is easier to argue that the accused should not profit from wrongdoing.").

167. See FED. R. EVID. 804(b)(6) advisory committee's note ("The usual Rule 104(a) preponderance of evidence standard has been adopted in light of the behavior the new Rule 804(b)(6) seeks to discourage."); see, e.g., United States v. Aguiar, 975 F.2d 45, 47 (2d Cir. 1992) (noting that in the past it has held that, if it is found that a defendant procured the absence of a witness, the defendant has waived her Sixth Amendment rights and the right to object on hearsay grounds).

168. See CAL. Evid. CodE $§ 1370$ (West Supp. 1999).

169. See Karleen F. Murphy, Note, A Hearsay Exception for Physical Abuse, 27 GoldEN GATE U. L. REV. 497, 497-98 (1997).

170. See Ruling, People v. Simpson, No. BA097211, 1995 WL 21768, at *5 (Cal. Super. Ct. Jan. 18, 1995). See supra notes 65-67 and accompanying text.

171. More specifically, section 1370 provides that a hearsay statement "is not made inadmissible by the hearsay rule ...." CAL. EVID. CODE $§ 1370(a)$ (West Supp. 1999). A statement may still be inadmissible for other reasons such as relevance or prejudice.

172. Id. § 1370(a)(1).

173. See FED. R. EVID. 803(3) (excepting from the hearsay rule statements of the declarant's "then existing state of mind, emotion, sensation, or physical condition (such as intent, plan, 
the state of mind is not at issue, but rather the events themselves. This exception makes no change to the existing rule of disallowing statements of belief, ${ }^{174}$ perhaps on the theory that statements of memory relate directly to actions taken by the defendant, whereas statements of belief are only indirectly related.

Second, the declarant must be unavailable by reason of privilege, disqualification, death, illness, or other conditions defined in section 240 of the California Evidence Code. ${ }^{175}$ This condition is consistent with the necessity basis for allowing hearsay statements when a witness is unavailable. ${ }^{176}$ By restricting its definition of unavailability, the second condition eliminates many instances in which the victim is voluntarily unavailable, such as when a victim recants prior statements, claims not to remember the incident, or simply chooses not to testify at trial.

Third, the statement must have been made "at or near the time of the infliction or threat of physical injury," been "in writing, ... electronically recorded, or made to a law enforcement official." ${ }^{178}$ These requirements are somewhat analogous to the Federal Rules' exception for a past recollection recorded statement. ${ }^{179}$ In both situations, a guarantee of trustworthiness is found in the reliability inherent in a record made while events were fresh in an individual's mind and they can be accurately reflected. ${ }^{180}$ A significant difference is that the past recollection recorded statement generally requires the declarant to be a witness, ${ }^{181}$ whereas section 1370 requires unavailability. The exception also specifically allows statements made

motive, design, mental feeling, pain, and bodily health), but not including a statement of memory or belief to prove the fact remembered or believed," unless the terms of a will are in dispute).

174. See CAL. Evid. Code $\S 1250$ (b) (West 1995) ("This section does not make admissible evidence of a statement of . . . belief to prove the fact . . . believed."). For example, the statement "I think he's going to kill me" expresses the belief of a declarant and therefore would be inadmissible.

175. See id. $\S 1370($ a)(2) (West Supp. 1999).

176. See supra notes $152-54$ and accompanying text.

177. CAL. Evid. CODE $\S 1370(a)(3)$ (West Supp. 1999).

178. Id. § 1370(a)(5).

179. See supra note 105 . The California exception is substantially similar. See CAL. EvID. CODE $§ 1237$ (West 1995).

180. See FED. R. EVID. 803(5) advisory committee's note.

181. A requirement in the California past recollection recorded exception is that the statement be introduced "after the witness testifies that the statement he made was a true statement of such fact." CAL. EvID. CODE $§ 1237(3)$ (West 1995). The Federal Rule does not explicitly require the testimony of the witness, but the language referring to the memory of the witness implies availability. See supra note 105. 
to law enforcement officials. ${ }^{182}$ As discussed previously, the trustworthiness of statements made to law enforcement officials may be somewhat questionable. ${ }^{183}$ Additionally, the exception excludes statements made more than five years before the filing of the current proceeding. ${ }^{184}$ Although this condition does not provide any greater guarantee of trustworthiness, ${ }^{185}$ it does exclude statements that may no longer be relevant. This is somewhat analogous, in a relevance sense, to the Federal Rule addressing impeachment of witnesses that excludes evidence of a witness's conviction of a crime if the conviction is more than ten years old. ${ }^{186}$ Here, however, the prior statement would not be introduced for impeachment purposes, but it would come dangerously close to being introduced to show the character of the accused in order to show action in conformity with that character. This type of evidence is explicitly prohibited, although the evidence would still be permissible for another purpose, such as to show motive, intent, identity, or opportunity. ${ }^{187}$ With the exception of intent as it relates to threats, any of these other purposes would be inapplicable. One commentator proposes a domestic abuse character exception to deal explicitly with this problem. ${ }^{188}$

Fourth, the statement must have been made "under circumstances that would indicate its trustworthiness." ${ }^{, 189}$ The rule provides further guidance in the determination of trustworthiness, citing as relevant factors " $[\mathrm{w}]$ hether the statement was made in contemplation of pending or anticipated litigation in which the declarant was interested," "[w]hether the declarant has a bias or motive for fabricating the statement, and the extent of any bias or motive,"

182. See CAL. Evid. CodE $§ 1370(a)(5)$ (West Supp. 1999).

183. See supra Part II.A.2; see also Evidence Law-Hearsay Rule-California Adopts Hearsay Exception Making Written Statements by Unavailable Witnesses That Describe Past Physical Abuse Admissible in Civil and Criminal Cases, 110 HARV. L. REV. 805, 809 (1997) [hereinafter Evidence Law] ("[T] he fact that a statement was made verbally to a police officer fails to provide any indication of the statement's accuracy or trustworthiness, unless one both accepts the romantic notion that police officers never distort the truth and believes that police officers' memories never fail.").

184. See CAL. Evid. CodE § 1370(a)(3) (West Supp. 1999).

185. See Evidence Law, supra note 183, at 809.

186. See FED. R. EvID. 609(b); see also Murphy, supra note 169, at 516 \& n.136 (arguing that the prohibition ensures that the incident is not so remote as to make the statement irrelevant).

187. See FED. R. EVID. 404(b); CAL. EVID. CODE § 1101(b) (West 1995).

188. See Raeder, supra note 10, at 1505 (proposing to permit relevant evidence of prior domestic violence in relationship cases).

189. CAL. EVID. CODE $§ 1370(a)(4)$ (West Supp. 1999).

190. Id. § 1370(b)(1).

191. Id. $§ 1370(\mathrm{~b})(2)$. 
the statement is corroborated by evidence other than statements that are admissible only pursuant to this section." ${ }^{192}$ Although the rule does not consider these the only possible relevant factors, these factors do not necessarily provide additional guarantees of trustworthiness, particularly given the circumstances under which the rule would be applied.

Examining the first of these factors, pending litigation, few would disagree that a statement made in contemplation of litigation may be untrustworthy because the witness has an interest in the use of the statement. ${ }^{193}$ The inverse, however, is not necessarily true. The fact that a statement was not made in contemplation of litigation does not mean the statement is trustworthy. Thus, while this factor may definitively exclude a statement, it is of little help in determining whether a statement is actually trustworthy.

On the surface, the second factor, bias or motive, is troublesome in light of the circumstances under which the hearsay exception is applied. Because the statement must be made "at or near the time of the infliction or threat of physical injury," ${ }^{, 194}$ there is a strong likelihood that the declarant's anger could result in bias. However, applying this type of analysis would essentially eliminate all relevant statements. Thus, a deeper examination of the presence of bias is necessary to determine the untrustworthiness of the statement.

The third factor, whether the statement is corroborated by others, poses the most significant problem: it conflicts with the Supreme Court's ruling in Idaho $v$. Wright. ${ }^{195}$ In that case, the Court indicated that the particular guarantees of trustworthiness required for admis-

192. Id. $\$ 1370(\mathrm{~b})(3)$.

193. See Palmer v. Hoffman, 318 U.S. 109, 113-15 (1943) (finding the primary utility of railroad accident records to be in "litigating, not in railroading," and holding records inadmissible because they were not "made 'in the regular course' of business"); see also FED. R. EVID. 803(6) advisory committee's note (discussing the motives of the preparer of business records and the admissibility of such records under the exception to the hearsay rule); 2 MCCORMICK ON EVIDENCE, supra note 2, $\$ 288$, at 256-57 (discussing Palmer and the trustworthiness of business records).

194. CAL. Evid. CODE $§ 1370(a)(3)$ (West Supp. 1999).

195. 497 U.S. 805 (1990); see Charles R. Nesson \& Yochai Benkler, Constitutional Hearsay: Requiring Foundational Testing and Corroboration under the Confrontation Clause, 81 VA. L. REV. 149, 166 (1995) (arguing that "[t]he specific component of evidence must be examined for its internal competence and credibility" because the Constitution does not allow the admittance of evidence that is incompetent and incredible by itself just because it would allow a conviction if considered in light of the rest of the evidence); Evidence Law, supra note 183, at 809 (discussing Wright's proposition that it is unconstitutional to admit evidence that "is incompetent and incredible by its own rights" just because in totality it may lead to a conviction); see also supra notes 146-48 and accompanying text (discussing Wright). 
sion under the Confrontation Clause must be drawn from the "totality of circumstances that surround the making of the statement." 196 The Court, however, restricted the analysis to only those circumstances surrounding the making of the statement itself. ${ }^{197}$ Furthermore, the Court held that " $[\mathrm{t}$ o be admissible under the Confrontation Clause, hearsay evidence used to convict a defendant must possess indicia of reliability by virtue of its inherent trustworthiness, not by reference to other evidence at trial." ${ }^{198}$ Thus, using corroborating evidence to establish trustworthiness is probably unconstitutional.

As evidenced in this discussion, section 1370 is poorly drafted and probably unconstitutional. Ironically, the very statements that the statute was designed to encompass, the statements of Nicole Brown Simpson, would likely still be inadmissible under the new exception. ${ }^{199}$ Perhaps for this reason, section 1370 was not used in the Simpson civil trial, even though it was enacted to be available for such use. ${ }^{200}$

\section{A NEW HEARSAY EXCEPTION}

As discussed previously, the arguments for the creation of a new hearsay exception are compelling. Furthermore, the barriers to implementing such an exception, while significant, are not insurmountable. The requisite necessity basis exists for the creation of such an exception, but some form of trustworthiness guarantees would have to be satisfied.

\footnotetext{
196. Wright, 497 U.S. at 820.

197. See id. at 819.

198. Id. at 822 .

199. Diary entries made by Nicole Brown Simpson would not have fallen within the fiveyear window required by section $1370(a)(2)$. Statements made to family and friends soon before her murder would likely have failed to meet the requirements of section 1370(a)(1) —narrating, describing, or explaining the infliction or threat of injury-or of section 1370(a)(5), because the statements were not recorded in writing, recorded electronically, or made to a law enforcement officer. Additionally, a call to a battered women's shelter may not have been admissible because it was not known whether the statement was made near the time of the infliction or threat of injury, as required by section 1370(a)(3). See Murphy, supra note 169, at 523-25.

200. The first citation to section 1370 at the appellate level (as reflected in a search of Lexis and Westlaw databases) was in the reversal of O.J. Simpson's grant of guardianship by the trial judge. See Simpson v. Brown, 79 Cal. Rptr. 2d 389 (Ct. App. 1998). The appellate judge held that the trial judge had erred in excluding Nicole Brown Simpson's diaries from the evidence at the guardianship hearing. See id. at 404 (stating that one of the clearest justifications for applying section 1370 is that it "was enacted specifically in response to the fact that these very diaries could not come into evidence in the criminal trial!"). But see Murphy, supra note 169, at 523-25 (arguing that the diaries would still be inadmissible under section 1370).
} 
Thus, a new exception would be both appropriate and feasible. ${ }^{201}$ Two questions remain: which situations warrant a new a hearsay exception, and what would be the required elements of a new exception?

\section{A. What Situations Warrant an Exception?}

The need to use hearsay statements in domestic abuse cases is the same whether the victim has died or is "voluntarily" unavailable..$^{202}$ It would, therefore, seem appropriate that a new hearsay exception be applicable to both situations. Because of some of the inherent differences in the types of evidence available in homicide and nonhomicide situations ${ }^{203}$ a different treatment may be warranted. However, similar statements may be made in each of these situations-for example, statements made prior to the incident, either recounting a past action of domestic violence or a threat of future violence. The admissibility requirements in these situations would be correspondingly similar. Thus, an exception based on when the statement was made would be more useful than one based on whether the incident was a homicide or nonhomicide. Given the similarity between the two situations, a single exception would be preferable to two separate exceptions for homicide and nonhomicide situations.

\section{B. What Would Be the Required Elements of an Exception?}

First, as indicated, the exception should account for both homicide and nonhomicide situations. This is especially necessary if prevention of recurring domestic violence and protection of the victim are goals of the criminal justice process in this context.

201. Many states currently have a residual hearsay exception. See supra notes 62-63 and accompanying text. In these states, a new hearsay exception designed specifically for domestic violence situations may not be necessary. However, the creation of an exception in these states would still be appropriate because it would provide a more specific tool for prosecutors, as well as emphasize that combating domestic violence is a priority for that jurisdiction.

202. See supra Part I.

203. For example, a homicide victim will rarely have the opportunity to make a statement concerning the events that led to the homicide. If such a statement is available, it may qualify as a dying declaration and may be admissible as an exception to the hearsay rule. See supra note 29. Otherwise, hearsay statements might include accounts of past actions of domestic violence or threats of future violence. The nonhomicide victim will usually have had the opportunity to make a statement concerning the events of the particular assault at issue in the case. 
Second, it should be made clear that the exception applies to the domestic violence context. While the new California exception, ${ }^{204}$ passed in the wake of the O.J. Simpson case, was intended to apply to domestic abuse cases, ${ }^{205}$ it does not distinguish between domestic violence and other types of violence. In order to focus the exception on the domestic violence context, the exception should be explicitly restricted to statements by a current (at the time of the statement) or former spouse or domestic partner. ${ }^{206}$

Third, the exception should, like the California exception, be restricted to statements that describe the infliction of a past injury or a threat of future injury upon the declarant ${ }^{207}$ - statements of belief, standing alone, should not be admissible. While a statement of belief (e.g., "I think he's going to kill me") may certainly indicate the critical state of a relationship, it does not provide the context for the belief. Rather, providing the facts underlying the belief (e.g., "he attacked before" or "he threatened me") gives the statement more reliability and ultimately makes the statement more probative and less prejudicial.

Fourth, the statement should be buttressed by additional trustworthiness guarantees. As required by the California exception, the statement should have been made at or near the time of the infliction or of the threat of injury ${ }^{208}$ - when the matter was fresh in the witness's memory. ${ }^{209}$ The firsthand knowledge of the declarant must be clearly shown, as required for any in-court testimony. ${ }^{210} \mathrm{~A}$ borderline state of excitement may also be a factor supporting the trustworthiness of the statement.

Fifth, the statement should also be recorded on videotape. ${ }^{211}$ Not only can a videotape provide an accurate record of the words of the

204. See CAL. EvID. CODE $\S 1370$. For an extended discussion of this section, see supra Part III.C.

205. See Murphy, supra note 169, at 497-98 (noting that section 1370 was passed in response to the finding of not guilty in the O.J. Simpson case).

206. See, e.g., Matthews, supra note 85, at 161-62 (proposing a hearsay exception with the requirement that " $[t]$ he declarant ... was the spouse or domestic partner or former spouse or domestic partner of the person against whom the statement is offered").

207. See CAL. EvID. CODE $\$ 1370(a)$ (1) (West Supp. 1999).

208. See id. \$1370(a)(3).

209. See FED. R. EVID. 803(5) advisory committee's note ("The guarantee of trustworthiness is found in the reliability inherent in a record made while events were still fresh in mind and accurately reflecting them.").

210. See id. 602 .

211. A statement recorded in writing or on audiotape may help in proving the accuracy of a statement, but it cannot be considered a proxy for appearance, and it is subject to concerns of 
victim, but a statement recorded on videotape can also act as a surrogate for personal presence at trial. The opportunity for a jury to be able to view the demeanor and physical appearance of the victim, as well as to detect any potential coercion, can significantly enhance the trustworthiness of the statement. ${ }^{212}$ At the very least, this would allow the jury to determine for itself the trustworthiness of the statement. Such videotapes should not be staged at a later time, however, as for a deposition. Rather, the admissible videotape should be made at the initial interview with the police or other official, in which the demeanor and physical appearance would provide an extra degree of trustworthiness. Furthermore, the potential impact of such a videotape-for example, if the victim appears disheveled (perhaps showing signs of physical violence), appears frightened, or is visibly recovering from a traumatic experience-could also play an extremely significant role. $^{213}$

Finally, there should be a notice requirement so as to provide the defendant with a fair opportunity to respond to the statement. ${ }^{214}$ While this notice would preferably occur before trial, the nature of a victim's testimony-i.e., that the victim may surprise the prosecution by recanting on the witness stand-allows notice to occur during trial.

\section{CONCLUSION}

Domestic violence is a serious problem in today's society. The ability of prosecutors to bring domestic abusers effectively to justice is made difficult by several factors: domestic violence incidents occur in private, the victim is often unavailable or unwilling to testify, and statements of the victim are barred by the hearsay rule. Although some jurisdictions avoid this problem by expanding existing hearsay exceptions to admit hearsay statements of the victim, a more appro-

lack of formality and potential coercion. See supra note 101.

212. Cf. Paul G. Cassell, Miranda's Social Costs: An Empirical Reassessment, 90 Nw. U. L. REV. 387, 487-88 (1996) (discussing the merits of videotaped interrogations in place of following the Miranda procedures).

213. The use of videotape when interviewing domestic violence victims may not always be practical, as such equipment may not always be available for use. See, e.g., State v. Villarreal, 889 P.2d 419, 427 (Utah 1995) (discussing the practicality of videotaping confessions). However, video recording equipment is becoming more readily available and more practical outside of the police station. See Heath S. Berger, Comment, Let's Go to the Videotape: A Proposal to Legislate Videotaping of Confessions, 3 ALB. L.J. SCI. \& TECH. 165, 178 (1993) (identifying the limitations of videotaping confessions outside the police station, but noting that advancing technology makes such videotaping more feasible).

214. See, e.g., FED. R. EVID. 807 (requiring that the proponent make his intent to use a statement known to an adverse party "sufficiently in advance of the trial or hearing"). 
priate solution would be to create a new exception specific to the domestic violence context. Such an exception is warranted by the need to use the hearsay statements at trial and to advance a policy of reducing domestic violence through the effective prosecution of domestic abusers. A new exception would have to have certain guarantees of trustworthiness to pass Confrontation Clause muster, but, through the use of videotape and other requirements, these guarantees can be provided. 